\title{
Report of the Committee for Bryophyta: 8
}

\section{Gea Zijlstra}

\author{
Nationaal Herbarium Nederland, Utrecht University branch, Heidelberglaan 2, NL-3584 CS Utrecht, Netherlands. \\ g.zijlstra@bio.uu.nl
}

The previous report of this Committee appeared in Taxon 51: 793-794. Jan 2003 ('Nov 2002'). Since then, the Committee has lost its Chairman, Dr. Riclef Grolle, who died on 12 June 2004. Riclef had been our Chairman since the $13^{\text {th }}$ IBC in Sydney (1981) and a member of this committee since the $11^{\text {th }}$ IBC in Seattle (1969). He was a delightful, humble, exceptionally knowledgeable person, and we will sorely miss his counsel.

Votes were taken in three ballots, with ten, ten, and nine members voting, respectively: L. Hedenäs (Sweden), J. Heinrichs (Germany; not third ballot), P. Isoviita (Finland), R. E. Magill (U.S.A.), S. M. Perold (South Africa), R. D. Seppelt (Australia), R. E. Stotler (U.S.A.), B. C. Tan (Singapore), J. Vána (Czech Republic) and G. Zijlstra (Netherlands, Secretary). A minimum of eight votes is required to recommend action on a proposal (adoption or rejection). The votes are recorded in the order yes : no : abstention.

(1498) Reject Riccia minima L. [Hepat.] (proposed by Perold, Taxon 50: 1187-1188. 2002). Votes: $10: 0: 1$ (recommended).

For more than a hundred years, Riccia minima has been considered a nomen ambiguum, and thus rejected informally. There is no extant Linnaean type material, so for typification only the three non-binomial elements cited by Linnaeus could be used. Doing so would, however, threaten the widely used names of one of two later-named species: $R$. nigrella DC. or $R$. sorocarpa Bisch., or of a name dating from the same publication, $R$. fluitans L.; this concerns a species complex that never has been considered as related to $R$. minima. Rejection to include the name in Appendix IV is recommended.

(1543) Reject Jungermannia globulifera Pollich [Hepat.] (proposed by Grolle, Taxon 51: 569. 2002). Votes: $10: 0: 1$ (recommended).

During our discussion to conserve Jungermannia exsecta (proposal accepted by this Committee, see Taxon 51: 793. 2003), the need emerged for J. globulifera to be rejected, because it not only threatened $J$. exsecta, but also Lophozie ventricosa or L. minor. Jungermannia globulifera has never been in use, and its identity is doubtful, so rejection and inclusion in Appendix IV are recommended.

(1544) Conserve Telaranea Spruce ex Schiffn. against Arachniopsis Spruce [Hepat.] (proposed by Engel \& Merrill, Taxon 51: 571-572. 2002). Votes: 10:0 : 1 (recommended).
Both of these genera have always been considered as closely related and in recent phylogenetic studies it appears that they should be united. Because Telaranea, the youngest one, is a much larger genus than Arachniopsis (ca. 90 and ca. 10 species, respectively), the Committee recommends conservation of Telaranea against Arachniopsis, with minor additions and a correction of the proposed text.

In Telaranea, the publication date (as a preprint) is Sep 1893 , and in the type paragraph, the new combination can be added, to read:

Typus: T. chaetophylla (Spruce) Schiffn. (Lepidozia chaetophylla Spruce).

In Arachniopsis, "Oct-Dec" should be added to the publication date, and the reference for the type designation should be entered in the type paragraph, to read:

Typus (vide R. M. Schust., Nova Hedwigia 10: 34. 1965): Arachniopsis coactilis Spruce.

(1579) Conserve Oxyrrhynchium (Schimp.) Warnst. with a conserved type [Musci] (proposed by Ignatov \& Isoviita, Taxon 52: 352-354. 2003). Votes: $10: 0: 1$ (recommended).

Oxyrrhynchium (itself a split-off from Eurhynchium) has been split up again. From phylogenetic studies based on both morphological and molecular data, the circumscription of Oxyrrhynchium s.str. became clear. When Robinson split off Stokesiella in 1967 (a later homonym, later renamed Kindbergia), he designated Eurhynchium hians as the type of Oxyrrhynchium. Eurhynchium hians was not, however, mentioned by Schimper when he created his subgenus (although he included the concept of this species, to which he misapplied the name Eurhynchium praelongum). Without conservation, E. praelongum (designated by Buck in 1988) would provide the type. This, however, belongs to Kindbergia. The Committee agrees that E. hians would be the most suitable type and that Oxyrrhynchium should be conserved in its current concept. Therefore, we recommend acceptance of the proposal. The earlier problems with the concept of E. praelongum (basionym: Hypnum praelongum) and E. hians (basionym: H. hians) have been removed by appropriate typifications by Hedenäs (Nova Hedwigia 62: 459. 1996) and Hedenäs \& Geissler (Candollea 54: 422. 1999), respectively.

(1596) Conserve Anthoceros with a conserved type [Hepat.] (proposed by Stotler \& Crandall-Stotler, Taxon 52: 628-629. 2003). Proposal superfluous and withdrawn.

After some discussion within the Committee, it became clear that the proposed type already is the type under strict 
application of the Code. The choice of A. punctatus was made several times, the first time by Evans in 1918, a choice that has often been overlooked. Evans was a good hepaticologist who worked on the basis of the American Code. In 1948, Proskauer chose the same species name, explicitly as a mechanical choice. The choice of A. punctatus was generally accepted in the next decades, e.g., on the printed ING card (1956) and in the Index Hepaticarum (1962). In other words, if one might argue that the 1918 and 1948 choices are supersedable under Art. 10.5 and *Ex. 7 of the present Code, one would arrive at the $I N G$ card designation of 1956.

Schuster, however, has another practice. Because $A$. punctatus is not specifically distinct from Aspiromitus husnotii, the type of Aspiromitus, he argued that A. punctatus is not available to be chosen as the type of Anthoceros: "By the 'law of residues', then, Anthoceros must be used for the other Linnean species, A. laevis and its relatives, of which Phaeoceros Prosk. (1951a) must be regarded as a synonym" (J. Hattori Bot. Lab. 26: 300. 1963). In 1992, Schuster explicitly designated A. laevis as the type of Anthoceros, thus using this generic name in a sense for which under the Code, the name Phaeoceros must be used. Recent phylogenetic investigations of the hornworts (Duff et al., Monogr. Syst. Bot. Missouri Bot. Gard. 98: 41-58. 2004) showed that Anthoceros (syn. Aspiromitus) is only loosely related to Phaeoceros / Anthoceros sensu Schuster.

When it became clear that under the Code, A. punctatus is the type of Anthoceros, the proposers have withdrawn their proposal.

(1597) Conserve Anthoceros agrestis against A. nagasakiensis [Hepat.] (proposed by Stotler \& CrandallStotler, Taxon 52: 629. 2003). Votes: $10: 0: 1$ (recommended).

A case of two taxonomic synonyms, a 25 year-old name and an old name that has very seldom been used (in Japan only), certainly not during the last 20 years. The Committee recommends acceptance of the proposal.

(1608) Conserve Jungermannia concinnata Lightf. with a conserved type [Hepat.] (proposed by Long, Taxon 53: 195. 2004). Votes $10: 0: 1$ (recommended).

By chance, original material of this species was found that belongs to three different species of Gymnomitrion (nom. cons.), not, however, to its type G. concinnatum that is based on $J$. concinnata. Therefore Long proposed a recently collected specimen from the original country (Scotland) to be accepted as the conserved type, and the Committee agrees.

(1609) Conserve Dicranoloma (Renauld) Renauld against Megalostylium Dozy \& Molk. [Musci] (proposed by Klazenga, Taxon 53: 196-197. 2004). Votes: $10: 0$ : 1 (recommended).

Unlike the previous proposal on this topic (rejected by our Committee, see Taxon 48: 564. 1999), this proposal was written by a specialist in the genus, who, after his revision, concluded that the original type of Dicranoloma, a name applied to a large genus, is not a problem, but that the earlier name of the small genus, Megalostylium, does indeed threaten it. The Committee recommends acceptance of the proposal.

(1610) Conserve Tortula solmsii (Schimp.) Limpr. against T. limbata Lindb. [Musci] (proposed by Cano, Taxon 53: 198-199. 2004). Votes: 10: $0: 1$ (recommended).

A case of two taxonomic synonyms, the older of which has seldom been used, and when referred to in synonymy has never been mentioned in a way that corresponds to the real identity of the type material. The Committee recommends acceptance of the proposal.

(1622) Conserve Jungermannia palmata Hedw. against Riccia fruticulosa O. F. Müll. [Hepat.] (proposed by Grolle, Taxon 53: 558-559. 2004). Votes: $9: 0: 2$ (recommended).

Jungermannia palmata is the basionym of Riccardia palmata (Hedw.) Carruth., the well-known name of a widespread boreal holarctic species. Recently it was proven that an older name for the same species exists: Riccia fruticulosa O. F. Müll., published in Flora Danica, of which the vol. \& fasc. number can best be cited as " $5(15)$ ". The Committee agrees that the latter was validly published, and that it threatens J. palmata; therefore the Committee recommends acceptance of the proposal. 